\section{Advocating contribution of private sector in fighting tuberculosis in India}

\section{Saurabh R. Shrivastava, Prateek S. Shrivastava, Jegadeesh Ramasamy}

Department of Community Medicine, Shri Sathya Sai Medical College and Research Institute, Kancheepuram, India

\section{Dear Editor,}

The global tuberculosis (TB) report revealed that in the year 2013, almost 11.7 million new cases of TB have been reported, of which India accounts for more than a quarter. ${ }^{1}$ Similar trends have been suggested even for drug resistant TB. ${ }^{1}$ The disease has reached enormous proportions in the country because of the favorable environmental attributes, weak public health care delivery system and limited involvement of all stakeholders. ${ }^{2,3}$

The private sector plays a crucial role in the Indian set-up as almost three-fourth of the country's population utilize private sector for their health related ailments preferentially. ${ }^{2}$ In-fact, for India to accomplish the Millennium Development Goal no. 6, the key strategy will be to include private sector within the existing strategies. ${ }^{4}$ Thus, to build linkages with the private sector and other health care establishments, the Revised National TB Control Program (RNTCP) has initiated multiple schemes, namely TB advocacy, communication, and social mobilization scheme; sputum collection center scheme; sputum pick-up and transport service scheme; designated microscopy-cum-treatment center scheme; laboratory technician scheme; culture and drug sensitivity testing scheme; treatment adherence scheme; slum scheme; TB unit scheme; and TB-HIV scheme, to promote the involvement of private sector. ${ }^{4,5}$ The basic idea behind these schemes is to assist the private sector financially and logistically to improve the reach of the services to remote areas of the country where public health sector is weak. ${ }^{4,5}$

The role of the program manager is crucial starting from the identification of the issues that need to be addressed; joint planning with the private provider; timely release of money; and to ensure regular monitoring and evaluation. ${ }^{2,45}$ In addition, the program managers have attempted to widen the horizon of services by establishing linkages with multiple professional associations for expanding the range of services. ${ }^{1,2}$ Thus, periodic trainings/sensitization sessions have been also organized to enlighten the private practitioners about the provisions involved in RNTCP.,4

In conclusion, incorporation of the private health sector in country's national program can significantly improve the range and reach of TB related diagnostic and therapeutic services. However, this necessitates active supervision by program managers and health care professionals to allow optimal participation of the private sector.

\section{References}

1. WHO. Global tuberculosis control report 2012. Geneva, Switzerland: World Health Organization; 2012.

2. IIPS. National family health survey (NFHS3) 2005-06. Mumbai, India: International Institute for Population Sciences Publ.; 2007. Available from: http://www.measuredhs.com/pubs/pdf/SR128/SR128.pdf

3. Shrivastava SR, Shrivastava PS,
Correspondence: Saurabh RamBihariLal Shrivastava, Department of Community Medicine, Shri Sathya Sai Medical College and Research Institute, Thiruporur-Guduvancherry main road, 603108 Kancheepuram, India Tel./Fax: $\quad+91.988 .422 .7224$ E-mail: drshrishri2008@gmail.com

Key words: private sector, tuberculosis, India.

Contributions: SS, conception and design, drafting of the article, review of literature, guarantor; PS, drafting of the article, review of literature, critical revision for important intellectual content; JR, general supervision of the research, overall guidance in writing the manuscript.

Conflict of interests: the authors declare no potential conflict of interests.

Received for publication: 24 0ctober 2014.

Revision received: 8 November 2014.

Accepted for publication: 8 November 2014 .

This work is licensed under a Creative Commons Attribution 3.0 License (by-nc 3.0).

(C) Copyright S.R. Shrivastava et al., 2014

Licensee PAGEPress, Italy

Healthcare in Low-resource Settings 2014; 2:4796 doi:10.4081/hls.2014.4796

Ramasamy J. Implementation of public health practices in tribal populations of India: challenges and remedies. Healthc Low Resour Settings 2013;1:e3.

4. TBC India. Managing the RNTCP in your area. A training course (Modules 5-9). Available from: http://tbcindia.nic.in/documents.html

5. TBC India. Guidelines for PMDT in India 2012. Available from: http://tbcindia.nic.in /documents.html 